\title{
DEVELOPMENT OF RECIPES AND ESTIMATION OF RAW MATERIAL FOR PRODUCTION OF WHEAT BREAD
}

Nina Osokina

Department of Technology of Storage and Processing of Grain Uman National University of Horticulture

1 Instytutska str., Uman, Ukraine, 20305 ninaosokina1953@gmail.com

Kateryna Kostetska

Department of Technology of Storage and Processing of Grain Uman National University of Horticulture

1 Instytutska str., Uman, Ukraine, 20305 kostetskakateryna@gmail.com

Helena Gerasymchuk

Department of Technology of Storage and Processing of Grain Uman National University of Horticulture

1 Instytutska str., Uman, Ukraine, 20305 elena.gerasim4uk@ukr.net

\section{Valeriia Voziian}

Department of Technology of Storage and Processing of Grain Uman National University of Horticulture

1 Instytutska str., Uman, Ukraine, 20305 voziian07@gmail.com

Lyubov Telezhenko

Department of restaurant and health promoting catering Odessa National Academy of Food Technologies

112 Kanatna str., Odessa, Ukraine, 65039 telegenko@ukr.net

\section{Olesia Priss}

Department of Technology of Processing and Storage of Agricultural Products Tavria State Agrotechnological University

18 B. Khmelnitsky ave., Melitopol, Ukraine, 72310 olesyapriss@gmail.com

\section{Valentina Zhukova}

Department of technology of processing and storage of agricultural products

Tavria State Agrotechnological University

18 B. Khmelnitsky ave., Melitopol, Ukraine, 72310 zhuzhuvf@gmail.com

\section{Valentyna Verkholantseva}

Department of processing and food production equipment named after professor F. Yalpachik

Tavria State Agrotechnological University 18 B. Khmelnitsky ave., Melitopol, Ukraine, 72310 milaeva.v@mail.ru 


\author{
Nadiya Palyanichka \\ Department of processing and food production equipment \\ named after professor F. Yalpachik \\ Tavria State Agrotechnological University \\ 18 B. Khmelnitsky ave., Melitopol, Ukraine, 72310 \\ palyanichkan@gmail.com \\ Dmytro Stepanenko \\ Department of «Ecology and Zoology» \\ Melitopol State Pedagogical University named after Bohdan Khmelnytsky \\ 20 Hetmanska str., Melitopol, Ukraine, 72313 \\ olesyapriss@gmail.com
}

\section{Abstract}

The study of technological parameters of Midas wheat flour and possibility to use little-spread plants at wheat bread manufacturing was realized. Parameters and regimes for keeping and baking bread of new recipes were elaborated and selected. The elaborated method of bread manufacturing by new recipes relates to the field of agriculture and food industry and may be used at a laboratory baking of bread.

There was experimentally grounded and introduced the change of a part of recipe quantity of wheat flour for dried and comminuted plants of Népeta mussinii L., Polymnia osotolysta L., Amaranthus tricolor L., Cosmos sulphureus L., Tanacetum parthenium L., Cyperus esculentus L., Physalis tomentous L. at baking bread. According to determined physical-chemical, organoleptic parameters of bread, a possibility of baking bread using plants was proved. The expedience of introducing vegetable additives of Népeta mussinii L., Polymnia osotolysta L., Amaranthus tricolor L., Tanacetum parthenium into wheat dough in the dose no more than $5 \%$ to the flour mass; up to $10 \%$ - Cosmos sulphureus L and up to $15 \%$ - Cyperus esculentus L., Physalis tomentous L was proved. At these very dosages bread had an evenly colored crust, without breaks and cracks, elastic crumb, thin-walled porosity, expressed bread taste and pleasant smell of additives as opposite to other experimental samples.

Keywords: Physalis tomentous L., Cyperus esculentus L., Cosmos sulphureus L., Polymnia osotolysta L., Amaranthus tricolor L., Népeta mussinii L., Tanacetum parthenium L., new recipes, bread products.

(C) Nina Osokina, Kateryna Kostetska, Helena Gerasymchuk, Valeriia Voziian, Lyubov Telezhenko, Olesia Priss, Valentina Zhukova, Valentyna Verkholantseva, Nadiya Palyanichka, Dmytro Stepanenko
\end{abstract}

\title{
1. Introduction
}

The selection of wheat varieties with determined technological characteristics guarantees quality bakery products [1].

There are no enough data as to using volatile-oil-bearing, technical, spicy-gustatory and vegetable plants at baking bread; it is urgent to deepen and widen studies for scientifically grounding ways and methods of their rational use, study of potential possibilities of spicy-gustatory plants as a raw material, widening of bakery assortment. The favorable ratio of the content of chemical components of these plants gives a possibility to produce new types of functional products [2, 3].

The important positive result of using spicy-fragrant herbs is noted also at baking bread [4]. To solve actual problems of the field, it is important to decrease the chemical load on the human organism [5]. At bread baking it is necessary to shorten or exclude the use of improvers and other food additives [6].

The addition of spicy-fragrant plants must improve consumption properties of food products that results also in the improvement of their chemical composition, assimilation of nutritive substances, energetic value, biological and organoleptic parameters [7, 8].

The realized studies are aimed at the determination of the technological appropriateness of Midas wheat seeds for producing flour and bread and using little-spread volatile-oil-bearing, technical, spicy-gustatory and vegetable plants for baking bread that allows to widen the assortment of bakery products. 
The following tasks were solved for attaining this aim:

- to study technological parameters of flour of Midas wheat seeds;

- to elaborate parameters and to select regimes for keeping and baking bread of new recipes;

- to determine physical-chemical, organoleptic parameters of bread;

- to establish the optimally possible recipe dosage of vegetable components at producing bread of new recipes.

\section{Materials and Methods}

Seeds of Midas soft wheat, used in the research, were planted on the experimental field of the farm "Bodniuk" in v. Granyv of Gaysinsky district of Vinnytsia region (Ukraine).

For baking bread the following plants were used: Népeta mussinii L., polymnia osotolysta L., Amaranthus tricolor L., Cosmos sulphureus L., Tanacetum parthenium L., Cyperus esculentus L., Physalis tomentous L.

Plants were cultivated in the Northern part of the Right-bank Forest-Steppe of Ukraine at fields of the laboratory medical botany of the National botanical garden, named after M. M. Gryshko, NAS of Ukraine.

Wheat flour was analyzed for the general content of protein by Kjedall Nx5,7 using the device Kjeltec 2400/2460 (Foss Analytical, Höganäs, Sweden).

Moisture of flour and bread was determined using the device SESH-3M (ISC "Mohyliv-Podylsky machine-building plant", Mohyliv-Podilsky, Ukraine), whiteness of flour - on the device Skib-M (SPE LTD "Acoustic plus", Krasnoperekopsk, AR, Crimea, Ukraine), fall number - PCHP-5 (LTD "MOTOTECH", Serpuhkov, Russia), gluten quality - "GDM-3M" ("Plavun-systems", Moscow, Russia).

Bread was baked in the laboratory stove (Brabender, $6 \mathrm{~kW}, 380 \mathrm{~V}$ ). The volume of bread was estimated by displacing millet seeds using the device RZ-BIO (OSC “Zagorsky optical-mechanical plant, Moscow, Russia) and expressed in cubic centimeters for kg of bread.

\section{1. Experimental procedures}

The study was realized in the Uman National University of gardening, National botanical garden, named after M.M. Gryshko, NAS of Ukraine and production complex of the farm "Bodnyuk" in v. Granyv, Gaysinsky district of Vinnitsya region (Ukraine).

The analyses of seeds, flour and bread were realized with exactness and logical successiveness, according the methods, described in standards (given below). In flour were determined: flour output; quality (color, smell, moisture, uncleanness, contamination); bakery properties (quality and quantity of gluten, fall number, whiteness, protein mass share).

In bread were studied: organoleptic parameters of quality (color, taste, smell), physical-chemical parameters of quality; culinary properties (volume, specific volume, porosity, moisture, acidity).

The studies were guided by the standards method: flour organoleptic parameters (SSU 46.004-99); quantity and quality of gluten - (SSU 4117; SSU ISO 21415-1; SSU ISO 21415-2; SS 13586); protein content - (SS 10846 and SSU-P-4117); fall numbers - (SS 27676-88; SS 30498); protein mass share - (SSU 4117; SS 10846); bread acidity - (SS 5670-51); bread porosity (SS5669-51); bread volume - (SS 5669); bread moisture - (SS 21094-75); laboratory bread baking (SS 27669-88); organoleptic estimations of bread - (SSU-P 4585:2006; SS 5667-65).

For preparing powder of Népeta mussinii L., polymnia osotolysta L., Cosmos sulphureus L., Tanacetum parthenium L., surface green part of plants was used, whereas for powder of Cyperus esculentus L. - tubers, and of Physalis tomentous L. - berries. These parts of plants were dried, comminuted in the laboratory mill up to $10^{-4}-10^{-1} \mathrm{~mm}$ and mixed for taking a recipe batch.

And for preparing amaranth flour, seeds of grain culture Amaranthus tricolor L, were used; they were comminuted in the laboratory mill up to particle size $30-40 \mathrm{mcm}$ and mixed for taking a recipe batch.

Powder and flour of plants were used to replace $5 \%, 10 \%$ and $15 \%$ of wheat flour. The indicated dosage of comminuted studied plants to wheat flour was selected based on experimental 
studies. At the content of vegetable additive more than $15 \%$ in bread of new recipes, organoleptic parameters worsened: crust with breaks and cracks, crumb is not elastic, porosity is thick-walled. It may be obviously explained by the decrease of gluten quality and quantity in the output mixture of comminuted plants and flour, because a part of gluten wheat flour decreases. In its turn, the introduction of comminuted studied plants less than $5 \%$, has no effect. Mixtures were prepared before each experiment.

Several methods [9-11] of the laboratory baking of bread of wheat flour that provides the use of potassium bromated or sugar in the recipe or without this ingredients are known.

According to the method of the state sort-testing [9] the dough recipe includes: flour of $70 \%$ output $-100 \mathrm{~g}$ (at moisture $14 \%$ ), pressed yeasts $-3 \mathrm{~g}$, sugar $-2,5 \mathrm{~g}$, salt $-1,3 \mathrm{~g}$, potassium bromate $-0,003 \mathrm{~g}$, ascorbic acid $-0,0075 \mathrm{~g}$, drinking water - according to the water-absorbing capacity of flour by the farinograph index that corresponds to the dough consistence $500 \mathrm{un}$. $\mathrm{f}$. After preparing dough and separating in pieces, forms are put in the thermostat for keeping up to the readiness and put to the stove at the temperature $200-220{ }^{\circ} \mathrm{C}(180-240 \mathrm{~min})$. But the shortcoming of the described method is the use of potassium bromate that is not always present in the set of laboratory reagents.

Other ways of preparing dough for the laboratory bread baking are also known. According to one of them [10], dough is prepared of the whole raw material, provided by the recipe, at once. Pressed yeast consumption for dough mellowing is $2,0-3,0 \%$ of the flour mass depending on its sort. The duration of dough fermentation is $150-180 \mathrm{~min}$ at the temperature $28-32{ }^{\circ} \mathrm{C}$. Bread is baked for $15-20 \mathrm{~min}$ at the temperature $200-220{ }^{\circ} \mathrm{C}$.

According to the other method [11] the whole amount of flour, water, yeast and salt is also mixed at once. But pressed yeast is dissolved in 3-4-time amount of water with the temperature $32-35{ }^{\circ} \mathrm{C}$, used for dough batch, and the solution of salt and flour is added. All components are accurately mixed to receive homogenous dough. The amount of water, necessary for receiving dough of the given moisture, is determined by the calculation. Pressed yeast consumption depending on flour sort, fermentation duration and yeast quality is $1,5-2,5 \%$. Fermentation duration 3,5-4,0 hours at the temperature $28-30^{\circ} \mathrm{C}$. In 50-60 min after batch starting, dough is rumpled. The dough readiness is determined by its acidity that increases in 1,5 times and by dough firmness that bends after a short-term pressure on the dough surface. Bread is baked for 15-20 min at the temperature $200-220^{\circ} \mathrm{C}$.

The use of longer dough fermentation at keeping in the form essentially decreases the volume output of bread and worsens its appearance - cracks and blisters appear.

But the described methods were elaborated only for wheat flour without additives.

Parameters and regimes of keeping and baking of bread of new recipes were selected as a result of experimental studies.

The ratios 0:100, 5:95, 10:90 and 15:85 of powder of studied plants were used for the laboratory baking. At preparing dough $100 \mathrm{~g}$ of the mixture of $70 \%$ output of wheat flour of the superior quality (moisture $14 \%$ ) and powder or flour of spicy-gustatory plants, pressed yeast $-1,5 \%$, salt $-1,5 \%$, drinking water - according to the water-absorbing capacity of flour, that corresponds to the dough consistence $500 \mathrm{un} \mathrm{f}$, according to the farinograph index or 52-55\% were taken. After dough preparing, it was fermented in the thermostat for $150-180 \mathrm{~min}$ at the temperature $28-32{ }^{\circ} \mathrm{C}$, then dough was processed, formed, put in forms and placed in the thermostat again. The end of dough keeping was determined organoleptically. Bread was baked with moistening of the baking chamber at the temperature $200-220^{\circ} \mathrm{C}$ during $15-20 \mathrm{~min}$.

According to mechanical recommendations [12], bread was estimated in 16 hours after baking.

Bread was organoleptically estimated according to the method [13], by seven trained participants of the tasting. The analysis was realized by appearance, color, taste and smell.

\section{Results}

Organoleptic and baking parameters of flour of Midas wheat are presented in Table $\mathbf{1 .}$

According to the assessment of four of Midas wheat (on the example of superior quality flour), there was established the correspondence of organoleptic properties (color, smell, taste) to 
norms [14] for superior quality flour comparing with standards. The studied flour has the smell and taste, inherent to wheat flour without side smells and smacks. It doesn't crackle at chewing.

Table 1

Parameters of the flour quality of Midas wheat

\begin{tabular}{|c|c|c|c|}
\hline Parameter & $\begin{array}{c}\text { Allowed norm } \\
\text { (SSU ISO 46.004-99)* }^{*}[14]\end{array}$ & Actual quality & $\begin{array}{l}\text { Conclusion as to cor- } \\
\text { respondence to norm }\end{array}$ \\
\hline Color & $\begin{array}{l}\text { White, with yellow tint / White, } \\
\text { with yellow tint /white with yeln } \\
\text { low or grey tint }\end{array}$ & white & corresponds \\
\hline Smell & $\begin{array}{l}\text { Inherent to wheat flour, without } \\
\text { side smells, not mouldy, not musty }\end{array}$ & $\begin{array}{l}\text { Inherent to wheat flour, without } \\
\text { side smells, not mouldy, not musty }\end{array}$ & Corresponds \\
\hline Taste & $\begin{array}{l}\text { Inherent to wheat flour, without } \\
\text { side smacks, not sour, not bitter, } \\
\text { must not crackle at chewing }\end{array}$ & $\begin{array}{l}\text { Inherent to wheat flour, without } \\
\text { side smacks, not sour, not bitter, } \\
\text { must not crackle at chewing }\end{array}$ & corresponds \\
\hline Moisture, $\%$, no more & 15 & 12,2 & corresponds \\
\hline Quantity of raw gluten, $\%$ & No less than $24,0 / 25,0 / 21,0$ & 24,4 & Superior quality \\
\hline group & I-II/I-II/I-II & II & \\
\hline $\begin{array}{l}\text { Units of } \\
\text { GDM device }\end{array}$ & $45-100$ & 84 & corresponds \\
\hline $\begin{array}{c}\text { Whiteness, } \\
\text { con. un of Skib -M device }\end{array}$ & No less than $54 / 36-53 / 12-35$ & 56 & Superior quality \\
\hline Acidity, degrees & No more than $3,0 / 3,5 / 4,5$ & 1,9 & Superior quality \\
\hline Fall number, s, no less & 160 & 332 & corresponds \\
\hline
\end{tabular}

Note: *-under the line-superior quality; after the line - 1 and 2 quality

Flour of Midas wheat has stable high bakery properties: gluten content corresponds to the one of superior quality flour and is $24,4 \%$; indices of GDM device correspond to II quality group by gluten quality (84un.) and are characterized as satisfactory weak gluten; fall number - $332 \mathrm{~s}$, that is twice more than set requirements; acidity $-1,9^{\circ}$; whiteness -56 conv. un., that doesn't exceed permissible norms for superior quality flour and corresponds to the optimal level for receiving high-quality bread.

There was observed the good water-absorbing capacity of flour, dough was knead fast (2 min.), was kept in the optimal consistence near $1 \mathrm{~min}$, then was actively liquefied.

According to organoleptic parameters, bread of Midas wheat flour (control) corresponds to set requirements: surface - even, without contamination, big cracks and breaks; crumb - thoroughly baked, elastic, restores the initial form fast, not sticky, not moist at touch, with developed even porosity, without traces of hardening.

The photo of bread of Midas wheat flour (control) is presented on Fig. 1.

Bread of new recipes a bit differs from control samples by its quality: crumb color - light and dark yellow, brown, a bit green: smell and taste - inherent to added plants (Fig. 2, 3).

In average, the general bakery assessment of wheat bread is 4,5-5,0 points (perfectly) with up to $15 \%$ of powder of Cyperus esculentus L. Physalis tomentous L. and up to $5 \%$ of 
Cosmos sulphureus L and in the control; 3,8-3,9 points (good) - with up to $5 \%$ of powder of Polymnia osotolysta L., Népeta mussinii L., Tanacetum parthenium L. Amaranthus tricolor L. And 3,0-3,4 points (satisfactorily) - for other samples.

Samples of bread, estimated as perfect and good had crust, evenly colored without breaks and cracks, elastic crumb, thin-walled porosity, expressed bread taste and pleasant smell of additives as opposite to other experimental samples.

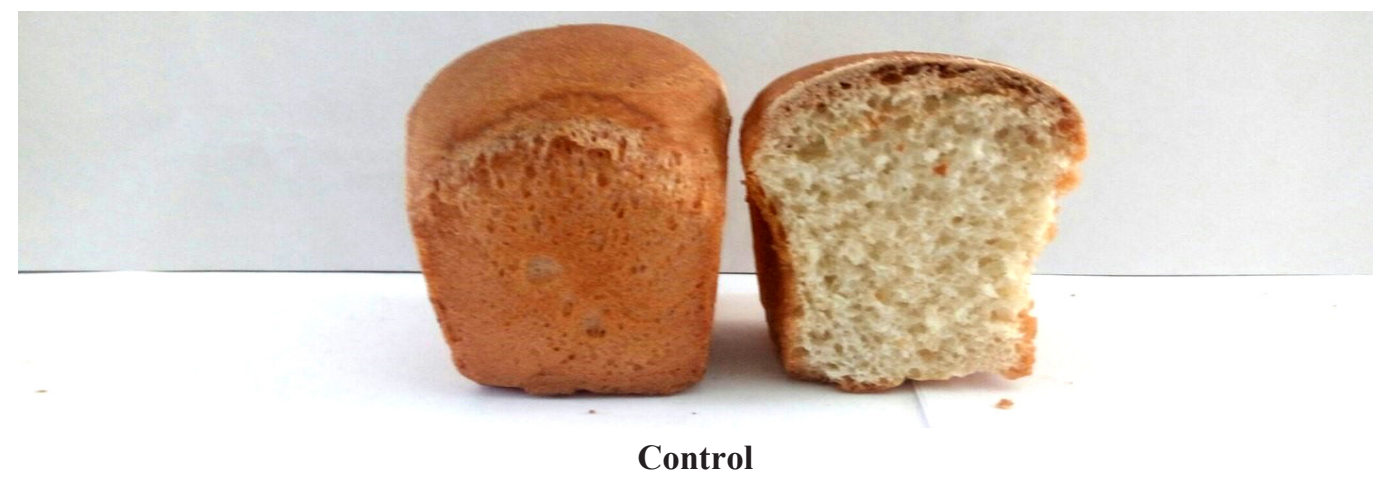

Fig. 1. The photo of bread of Midas wheat flour (control)



$5 \%$

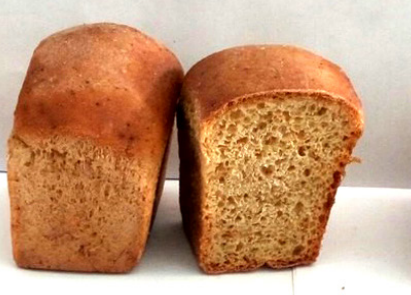

$10 \%$

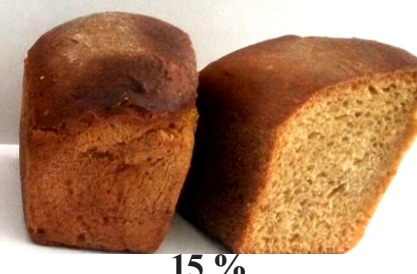

$15 \%$

Physalis tomentous

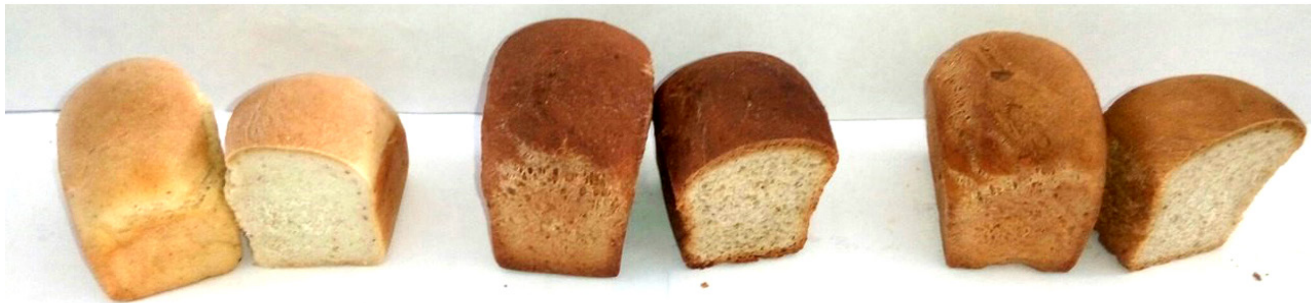

$5 \%$

$15 \%$
$10 \%$

Cyperus esculentus

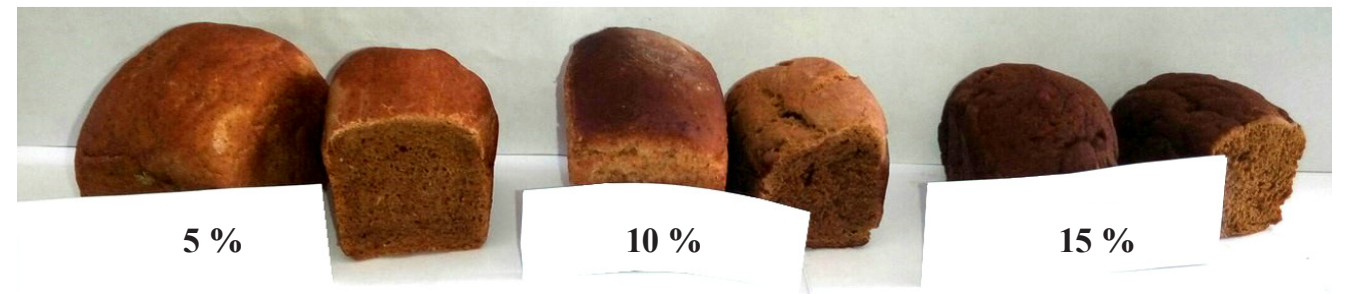

\section{Cosmos sulphureus}

Fig. 2. The photo of bread with 5, 10 and $15 \%$ of powder of plants Physalis tomentous L., Cyperus esculentus L. and Cosmos sulphureus $L$.

In Table 2 are presented physical-chemical quality parameters of bread of Midas wheat four (control) and new recipes. 


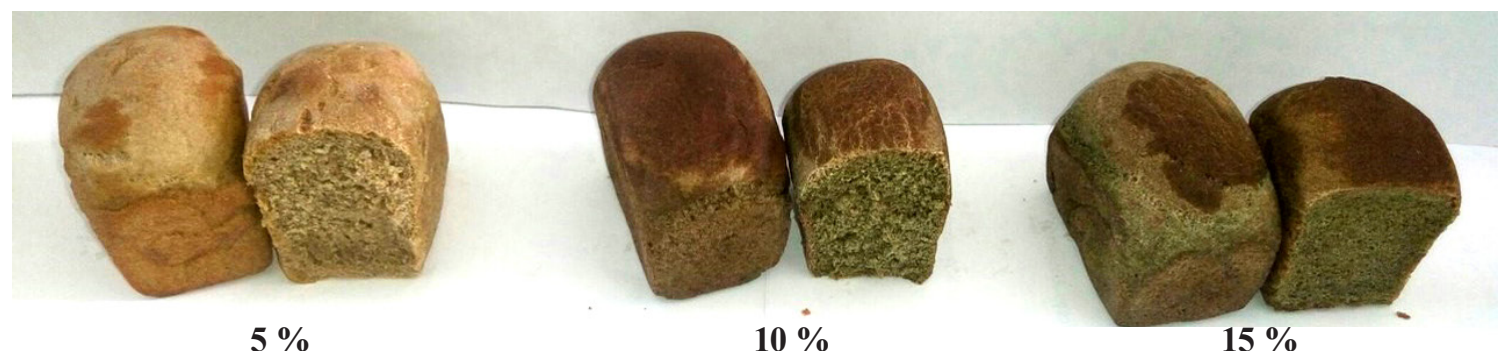

Polumnia osotolysta

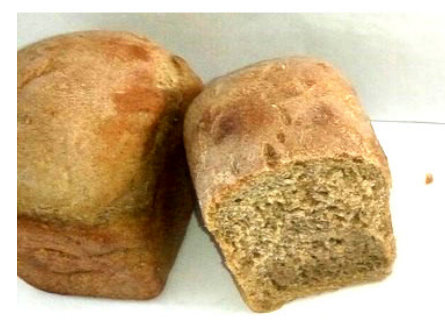

$5 \%$

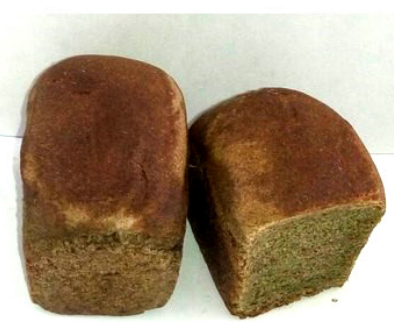

$10 \%$

Népeta mussinii



$15 \%$

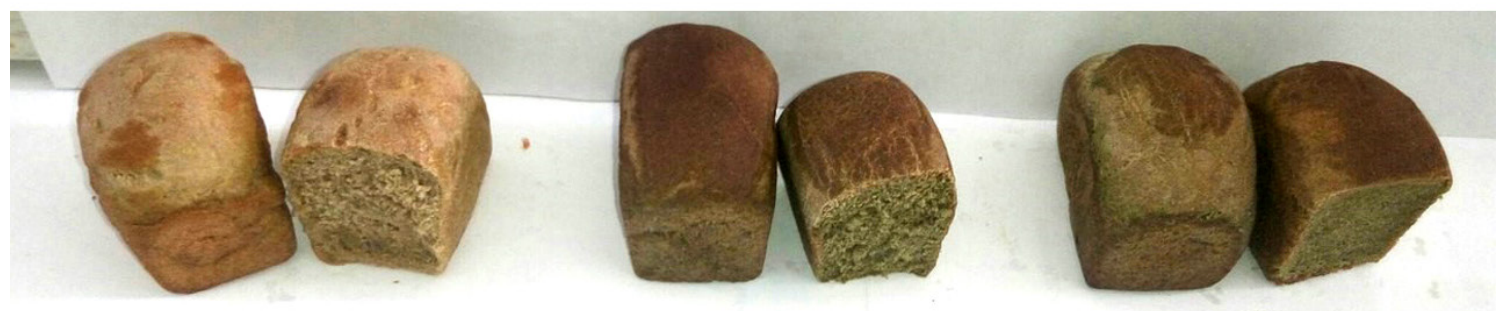

$5 \%$

$10 \%$

$15 \%$

Tanacetum parthenium

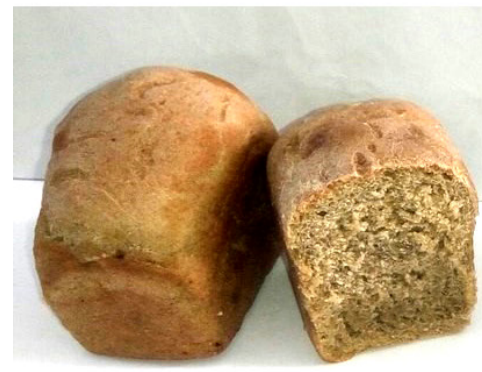

$5 \%$

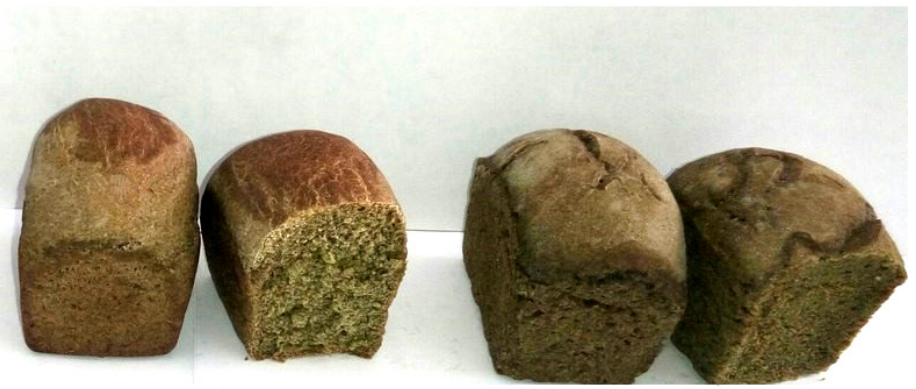

$10 \%$

$15 \%$

\section{Amaranthus tricolor}

Fig. 3. The photo of bread with 5, 10 and $15 \%$ of powder of Polymnia osotolysta L., Népeta mussinii L., Tanacetum parthenium L.and flour of Amaranthus tricolor L.

The increase of acidity in studied samples by 38-45\% comparing with control ones and more intense acid-accumulation in dough experimental samples is conditioned by the content of organic acids in this vegetable raw material and may be connected with intensification of lactate fermentation, that testify to creation of more favorable conditions for lactate bacteria.

In crumb of new samples of bread may be seen particles of enhancing additive, which presence at dough preparing had obviously negative influence on properties and construction of dough gluten carcass. 
Table 2

Physical-chemical parameters of bread quality

\begin{tabular}{|c|c|c|c|c|c|c|c|}
\hline \multicolumn{2}{|c|}{$\begin{array}{l}\text { Bread of wheat flour } \\
\text { (seed of Midas variety) }\end{array}$} & Mass, g & Moisture, \% & $\begin{array}{c}\text { Acidity of } \\
\text { crumb, degrees }\end{array}$ & Porosity, \% & Volume, $\mathbf{c m}^{3}$ & $\begin{array}{c}\text { Specific } \\
\text { volume, } \mathrm{cm}^{3} / \mathrm{g}\end{array}$ \\
\hline \multicolumn{2}{|l|}{ Control 1} & 35 & 46,6 & 1,6 & 72,9 & 3,31 & 0,090 \\
\hline \multirow{3}{*}{$\begin{array}{c}\text { Népeta } \\
\text { mussinii L }\end{array}$} & $5 \%$ & 36 & 47,5 & 2,7 & 69,9 & 2,72 & 0,076 \\
\hline & $10 \%$ & 36 & 47,7 & 3,3 & 69,8 & 2,69 & 0,075 \\
\hline & $15 \%$ & 35 & 47,9 & 3,4 & 67,5 & 2,64 & 0,075 \\
\hline \multirow{3}{*}{$\begin{array}{c}\text { Polymnia } \\
\text { osotolysta L. }\end{array}$} & $5 \%$ & 37 & 43,3 & 2,7 & 66,4 & 2,71 & 0,073 \\
\hline & $10 \%$ & 36 & 43,5 & 3,7 & 58,4 & 2,48 & 0,069 \\
\hline & $15 \%$ & 36 & 43,7 & 3,8 & 58,1 & 2,44 & 0,068 \\
\hline \multirow{3}{*}{$\begin{array}{l}\text { Amaranthus } \\
\text { tricolor L }\end{array}$} & $5 \%$ & 38 & 47,2 & 2,9 & 66,2 & 2,80 & 0,074 \\
\hline & $10 \%$ & 37 & 47,6 & 3,8 & 59,7 & 2,76 & 0,074 \\
\hline & $15 \%$ & 37 & 47,9 & 3,9 & 54,6 & 2,70 & 0,073 \\
\hline \multirow{3}{*}{$\begin{array}{c}\text { Cosmos } \\
\text { sulphureus L. }\end{array}$} & $5 \%$ & 37 & 46,6 & 2,8 & 66,4 & 2,79 & 0,075 \\
\hline & $10 \%$ & 36 & 47,0 & 2,9 & 66,2 & 2,56 & 0,071 \\
\hline & $15 \%$ & 36 & 48,1 & 2,9 & 62,7 & 2,52 & 0,070 \\
\hline \multirow{3}{*}{$\begin{array}{c}\text { Tanacetum } \\
\text { parthenium L. }\end{array}$} & $5 \%$ & 38 & 41,7 & 2,8 & 66,6 & 2,86 & 0,075 \\
\hline & $10 \%$ & 36 & 42,2 & 3,7 & 65,6 & 2,67 & 0,074 \\
\hline & $15 \%$ & 35 & 43,2 & 3,7 & 64,7 & 2,60 & 0,074 \\
\hline \multirow{3}{*}{$\begin{array}{c}\text { Cyperus } \\
\text { esculentus L }\end{array}$} & $5 \%$ & 35 & 41,7 & 2,6 & 69,7 & 3,16 & 0,090 \\
\hline & $10 \%$ & 34 & 42,5 & 2,7 & 67,6 & 3,03 & 0,089 \\
\hline & $15 \%$ & 34 & 43,3 & 2,7 & 66,3 & 3,02 & 0,089 \\
\hline \multirow{3}{*}{$\begin{array}{c}\text { Physalis } \\
\text { omentous L. }\end{array}$} & $5 \%$ & 37 & 46,5 & 2,8 & 78,8 & 3,42 & 0,093 \\
\hline & $10 \%$ & 37 & 47,1 & 2,9 & 74,2 & 3,36 & 0,091 \\
\hline & $15 \%$ & 36 & 47,3 & 2,9 & 73,3 & 3,31 & 0,091 \\
\hline$I E D_{05}$ & & 1,70 & 2,34 & 0,15 & 3,28 & 0,16 & 0,001 \\
\hline
\end{tabular}

\section{Conclusions}

1. Flour of Midas wheat seeds corresponds to permissible norms and to the optimal level for receiving bread, high-quality by all quality parameters.

2. The method of production of bread of new recipes relates to the field of agriculture and food industry and may be used at the laboratory baking of bread. The recommended way of wheat bread baking includes the change of $5-15 \%$ of wheat flour for powder (flour) of spicy-gustatory plants, with the addition of pressed yeast and kitchen salt in amount $1,5 \%$ of each one, drinking water in amount $52-55 \%$ of mass of the mixture of wheat flour and plants powder, fermentation in the thermostat (temperature $28-32{ }^{\circ} \mathrm{C}$ ) during $150-180 \mathrm{~min}$ and baking during $15-20 \mathrm{~min}$ at the temperature $200-220^{\circ} \mathrm{C}$.

3. Bread of new recipes corresponds to permissible norms by physical-chemical quality parameters. But porosity, volume and specific volume of products at using spicy-gustatory plants were inferior to the control sample by $4-11 \%, 4-26 \%, 1,1-24 \%$ respectively, except the sample with powder of Physalis omentous L. , in which these physical parameters were higher than the control ones by $7 \%, 0,5-3,2 \%$ and $1,1-3,2 \%$ respectively.

4. Bread of wheat flour corresponds to set quality requirements by organoleptic parameters. Bread of new recipes a bit differs from control samples by quality: crumb coloration - light and dark yellow, brown, a bit green, taste and smell - inherent to added plants.

5. It is expedient to introduce vegetable additives of Népeta mussinii L., Polymnia osotolysta L., Amaranthus tricolor L., Tanacetum parthenium into wheat dough in the dose no more than $5 \%$ to the flour mass; up to $10 \%$ - Cosmos sulphureus L and up to $15 \%$ - Cyperus esculentus L., 
Physalis tomentous L. At these very doses bread was estimated as perfect (4,5-5,0 points) and good $(3,8-3,9$ points) by organoleptic parameters.

6. In further Cyperus esculentus L., Physalis tomentous L. and Cosmos sulphureus L may be selected as best ones, expedient to be used at preparing also other groups of grain food products. It is provided to decrease the amount of powder of spicy-gustatory plants in the recipe composition of bread that received the satisfactory mark by the organoleptic analysis.

\section{Acknowledgments}

Help on provision (planting, collection, drying) of little-spread volatile-oil-bearing, technical, spicy-gustatory and vegetable plants for realizing the studies was given by the research associates of the National botanical garden, named after M. M. Gryshko, NAS of Ukraine: S. M. Kovtun-Vodyanitska, D. B. Rahkmetov, O. P. Bondarchuk, O. L. Andruschenko and others.

\section{References}

[1] Podpryatov, G. I., Rozhko, V. I., Skaletska, L. F. (2014). Technology of storage and processing of crop production. Kyiv: Agrarian education, 393.

[2] Zhemela, G. P., Shhemavnev, V. I., Oleksik, O. M. (2003). Technology of storage and processing of crop production. Poltava, 420.

[3] Koryachkina, S. Ya., Osipova, G. A., Khmelevova, E. V. et. al. (2012). Perfection of technologies of bakery, confectionery and macaroni products of functional purpose. Orel: FGBOOU VPO «State University-UNPK», 262.

[4] Gunathilake, K. D. P. P., Abeyrathne, Y. M. R. K. (2008). Incorporation of coconut flour into wheat flour noodles and evaluation of its rheological, nutritional and sensory characteristics. Journal of Food Processing and Preservation, 32 (1), 133-142. doi: 10.1046/j.1439-0361.2003.02062.x

[5] Do Carmo Barbosa Mendes de Vasconce, M., Bennett, R. N., Rosa, E. A. S., Ferreira-Cardoso, J. V. (2009). Industrial processing effects on chestnut fruits (Castanea sativaMill.). 2. Crude protein, free amino acids and phenolic phytochemicals. International Journal of Food Science \& Technology, 44 (12), 2613-2619. doi: 10.1111/j.1365-2621.2009.02092.x

[6] Rosell, C. M. (2003). The nutritional enhancement of wheat flour. Bread Making. Cambridge: Woodhead Publishing, 253-269. doi: 10.1533/9781855737129.1.253

[7] Indrani, D., Soumya, C., Rajiv, J., Venkateswara Rao, G. (2010). Multigrain bread - its dough rheology, microstructure, quality and nutritional characteristics. Journal of Texture Studies, 41 (3), 302-319. doi: 10.1111/j.1745-4603.2010.00230.x

[8] Dhingra, S., Jood, S. (2004). Effect of flour blending on functional, baking and organoleptic characteristics of bread. International Journal of Food Science and Technology, 39 (2), 213-222. doi: 10.1046/j.0950-5423.2003.00766.x

[9] Soroka, V. I., Andryushchenko, A. V., Shovgun, O. O. (2011). Method of state sort testing. State Commission of Ukraine for testing and protection of plant varieties. Kyiv: Allefa, 7 (2), 108.

[10] Drobot, V. I. (2002). Baking production technology. Kyiv: Logos, 155-156.

[11] Roiter, I. M. (1972). Directory of bakery production. Moscow: Food Industry, 2, 240-241.

[12] SS 5667-65. Bread and bakery products. Rules of acceptance, methods of sampling, methods for determination of organoleptic characteristics and mass (1996). Moscow: State standard, 5.

[13] SSU 4585:2006. Bakery products. Specifications (2006). Kyiv: State standard Ukraine, 14.

[14] SSU 46.004-99. Wheat flour. Specifications (1999). Kyiv: State standard Ukraine, 17. 